\begin{tabular}{|l|l|l|l|l|l|l|}
\hline Rev. Intropica & ISSN 1794-161X & Vol. 12 & No. 2 & $101-108$ & julio - diciembre de 2017 & Santa Marta, Colombia \\
\hline
\end{tabular}

\title{
NEW RECORDS OF PREDATION ON EGGS OF Bemisia tabaci (Hemiptera: Aleyrodidae) BY Chrysopodes (Chrysopodes) Lineafrons (Neuroptera: Chrysopidae) IN NORTHWESTERN ARGENTINA
}

\author{
NUEVOS REGISTROS SOBRE LA DEPREDACIÓN DE HUEVOS DE Bemisia tabaci (Hemiptera: \\ Aleyrodidae) POR Chrysopodes (Chrysopodes) Lineafrons (Neuroptera: Chrysopidae) EN EL \\ NOROESTE DE LA ARGENTINA
}

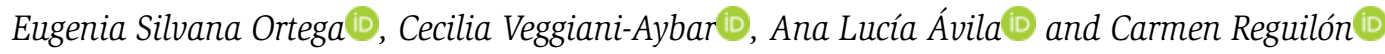

\begin{abstract}
Bemisia tabaci has become one of the major pests of economic importance that affects several crops worldwide. Among their natural enemies are found the Chrysopidae family, with larvae predators of different pests resulting very effective biological control agents. In order to contribute to possible use of this beneficial insect in B. tabaci biological control, the developmental time and survival of the immature stages of Chrysopodes (Chrysopodes) lineafrons was determined, as well as longevity and oviposition of the adults fed with eggs of $B$. tabaci $C$. (C.) lineafrons adults were collected in tomato crops in Lules department, Tucumán province. To determine the developmental duration for each instars and survival of the larvae, 90 eggs of $C$. (C.) lineafrons were randomly selected, of which only 71 eggs hatched; of these, 34 larvae were fed with B. tabaci eggs and 37 with Sitotroga cerealella eggs, used as control. The oviposition and longevity of the adults were recorded, both fed with the two preys. $C$. $(C$.) lineafrons larvae consumed an average 127.04 ( \pm 40.2) eggs of B. tabaci and 44 ( \pm 19.04) eggs of S. cerealella per day. Mean developmental time of $C$. (C.) lineafrons fed with B. tabaci eggs was 45 ( \pm 3.54) days and 35 ( \pm 5.04) days with $S$. cerealella eggs. Survival of immature stages, number of eggs per adults and their longevity were higher when $C$. (C.) lineafrons were fed with $S$. cerealella eggs than with B. tabaci eggs. Chrysopodes $(C$.) lineafrons has proved to be an efficient predator which would represent an excellent tool for B. tabaci biological control in tomato crops.
\end{abstract}

KEY WORDS: green lacewing; whitefly; predation capacity

RESUMEN

Bemisia tabaci se ha convertido en una de las principales plaga de importancia económica, afectando a diversos cultivos en todo el mundo. Entre sus enemigos naturales se encuentran las especies de la familia Chrysopidae, con larvas depredadoras de diferentes plagas que resulta un agente de control biológico muy efectivo de diferentes plagas. Para contribuir al posible aprovechamiento de este insecto benéfico en el control biológico de $B$. tabaci, se determinó el tiempo de desarrollo y supervivencia de los estadios inmaduros de Chrysopodes (Chrysopodes) lineafrons, y la longevidad y oviposición de los adultos alimentados con huevos de $B$. tabaci. Los adultos de C. (C.) lineafrons fueron recolectados en cultivos de tomate en el departamento Lules, provincia de Tucumán. Para determinar la duración del desarrollo de cada estadio y la supervivencia de las larvas, se seleccionaron aleatoriamente 90 huevos de $C$. (C.) lineafrons, de los cuales sólo 71 huevos eclosionaron; de estas, 34 larvas fueron alimentadas con huevos de $B$. tabaci y 37 con huevos de Sitotroga cerealella, utilizados como control. Se registró la oviposición y la longevidad de los adultos alimentados con las dos presas. Las larvas de C. (C.) lineafrons consumieron un promedio de 127,04 $( \pm 40,2)$ huevos de B. tabaci y $44( \pm 19,04)$ huevos de $S$. cerealella por día. El tiempo promedio de desarrollo de $C$. $(C$.) lineafrons alimentados con huevos de B. tabaci fue de 45 días $( \pm 3,54)$; mientras que los alimentados con huevos de $S$. cerealella fue de 35 días $( \pm 5,04)$. La supervivencia de los estadios inmaduros, el número de huevos por adultos y la longevidad fue mayor cuando $C$. (C.) lineafrons fueron alimentados con huevos de S. cerealella que con los huevos de B. tabaci. C. (C.) lineafrons demostró ser un depredador eficiente, representando así una excelente herramienta para el control biológico de B. tabaci en cultivos de tomate.

PALABRAS CLAVE: crisopa; mosca blanca; capacidad de depredación

DIRECCIÓN DE LOS AUTORES:

Instituto Superior de Entomología “Dr. Abraham Willink”, Facultad de Ciencias Naturales e Instituto Miguel Lillo, Universidad Nacional de Tucumán, Tucumán, Argentina, e-mail: eugesortega@gmail.com, ORCID:0000-0002-8339-1160 (E.S.O); e-mail: ceciliaveggianiaybar@yahoo.com. ar, ORCID: 0000-0001-6689-2767 (C.A.V.A). Estación Experimental Agroindustrial Obispo Colombres, Tucumán, Argentina, e-mail: avilanalucia@ yahoo.com.ar, ORCID: 0000-0001-7458-4991 (A.L.A.). Fundación Miguel Lillo, Tucumán, Argentina, e-mail: c_reguilon@yahoo.com.ar, ORCID: 0000-0001-7458-4991 (C.R.). 


\section{INTRODUCCIÓN}

The whitefly Bemisia tabaci Gennadius (Hemiptera: Aleyrodidae) is a serious pest of several annual crops, ornamental, industrial, fruit and weeds worldwide (Byrne et al., 1990; Brown et al., 1995; Viscarret, 2000; López-Ávila, 2005). It causes direct damage through sucking sap and the excretion of sugary substances that produce the growth of sooty mold, which causes decrease of the photosynthetic capacity of plant; also causes indirect damage by transmitting viruses and bacterias (Berlinger, 1986; Viscarret, 2000). The species of B. tabaci has caused significant losses in America since 1981, reducing crop productivity of tomato, sweet pepper, beans and textiles (Brown, 1993). In Argentina, the first record of $B$. tabaci arises from specimens found on unspecified host plant in Tucumán province (Viscarret, 2000). Subsequently, its presence is reported in greenhouses and field crops such as cotton, tobacco, citrus, sugar cane, soybean, forestry and horticultural crops of the families Solanaceae, Cucurbitaceae, Brassicaceae and Asteraceae (Polack, 2005).

Currently, the most used control method against B. tabaci is chemical control; however, an alternative method is based on biological control using natural enemies of the pest in order to decrease its density (Reguilón et al., 2011; Flores et al., 2015), the environmental impact and to improve product quality (López et al., 1999). Among their natural enemies is found the genus Chrysopodes Navás (Neuroptera: Chrysopidae), of cosmopolitan distribution and with about 40 species distributed in two subgenera, Chrysopodes s. str. and Neosuarius Adams and Penny
(Adams and Penny, 1987). In Argentina, the species Chrysopodes (Chrysopodes) lineafrons Adams and Penny, Chrysopodes (Chrysopodes) polygonicus Adams and Penny, Chrysopodes (Neosuarius) divisus Walker and Chrysopodes (Neosuarius) porterinus Navás have been reported (Adams and Penny, 1987; González-Olazo et al., 1999; Monserrat and Freitas, 2005; González-Olazo and Reguilón, 2008; Ortega et al., 2014).

Chrysopodes (C.) lineafrons is considered as an effective predator in biological control, however it is necessary to investigate the preference for certain pest species or even pest stage to be controlled as well as a possible interaction with other natural enemies. As such knowledge is deficient in the literature, an assay to study life cycle of $C$. (C.) lineafrons fed with eggs of B. tabaci as prey was set up. Therefore, developmental time, survival, longevity and oviposition as biological parameters of $C$. $(C$.) lineafrons were studied, as well as their predation ability over B. tabaci eggs under laboratory conditions.

\section{MATERIALS AND METHODS}

\section{Study area and collection of specimens}

Entomological sampling was performed during the period 2009-2010 in two greenhouses and one field of tomato crop in Lules department $\left(26^{\circ} 55^{\prime} 60^{\prime \prime} \mathrm{S}-65^{\circ} 20^{\prime}\right.$ 60” W, 382 m.a.s.l), Tucumán province, northwestern Argentina (Figure 1).

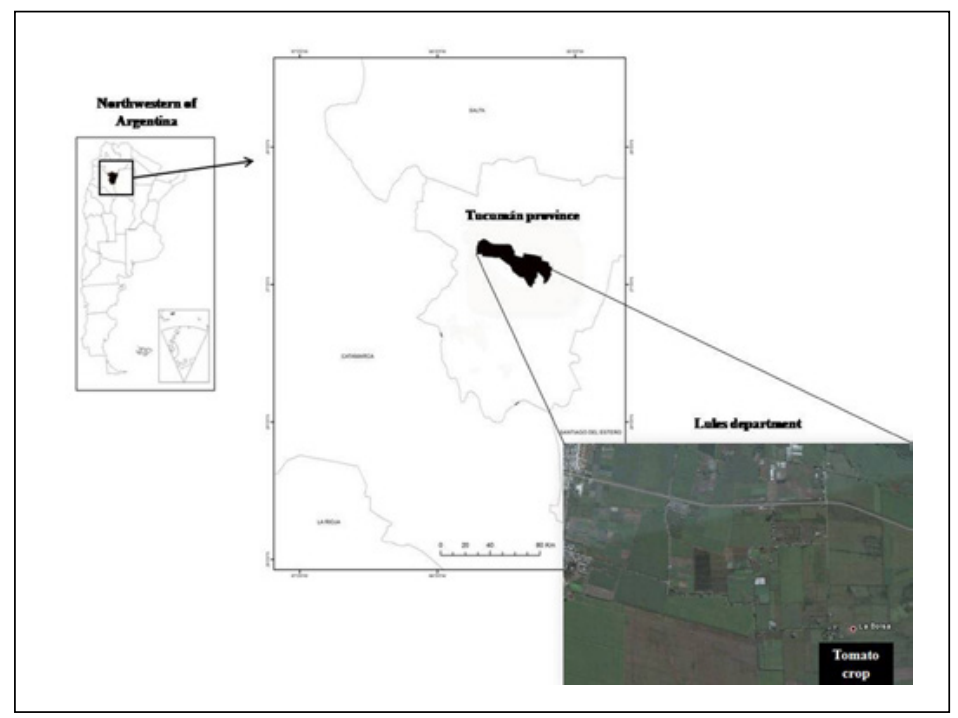

102 Figure 1. Geographical location of the tomato crops in Tucumán Province, northwestern Argentina. 
Chrysopodes $(C$.) lineafrons specimens were collected in tomato crops and the surrounding vegetation using manual aspirators for the adults and manually with a brush for the immature stages. Subsequently, adults were placed in plastic containers of $500 \mathrm{~cm}^{3}$ covered with voile and larvae in petri dishes with paper accordions, used to avoid cannibalism, and feeding with Sitotroga cerealella Oliver eggs.

\section{Assay in laboratory}

Rearing of $C$. (C.) lineafrons was maintained for 12 months. The adults were placed in $5 \mathrm{~L}$ plastic containers covered with voile, secured with an elastic band and properly labeled with the date of the collect and the number of individuals. A circular paper was placed inside the container for the females to lay eggs. They were fed daily with a mixture of yeast, pollen, honey and water in a proportion 10-1-5-7 and provided water with moistened cotton (Nuñez, 1988; Holguin et al., 2004; Reguilón et al., 2006).

To evaluate the ingestion of $C$. $(C$.) lineafrons, eggs breeding in the laboratory were selected randomly and placed in individual plastic containers of $2 \mathrm{~cm}$ diameter with hermetic seal, maintained at $27^{\circ} \mathrm{C}, 65 \%$ humidity and a photoperiod of 12: 12 (L: D) until hatching (DíazAranda and Monserrat, 1990; Giffoni et al., 2007) Once lacewing larvae emerged, they were separated in two groups. A known number of eggs of $B$. tabaci (190.3 \pm 113.2) were offered to one of the groups and $S$. cerealella eggs $(122.9 \pm 45.0)$ to the other, the latter used as a control, because it is the most used prey for the mass rearing of species of green lacewing. After 24 hours, the number of eggs predated and the $C$. $(C$.) lineafrons larvae survival were recorded (Legaspi et al., 1994; Hagler et al., 2004).

When the larvae of $C$. (C.) lineafrons achieved the pupal stage, they were placed in $1 \mathrm{~L}$ plastic containers covered with voile. The number of adults that emerged was recorded in each repetition and it were fed and maintained under the same conditions that the adults of breeding. The number of eggs laid and longevity of adults was registered every 24 hours (Figure 2).

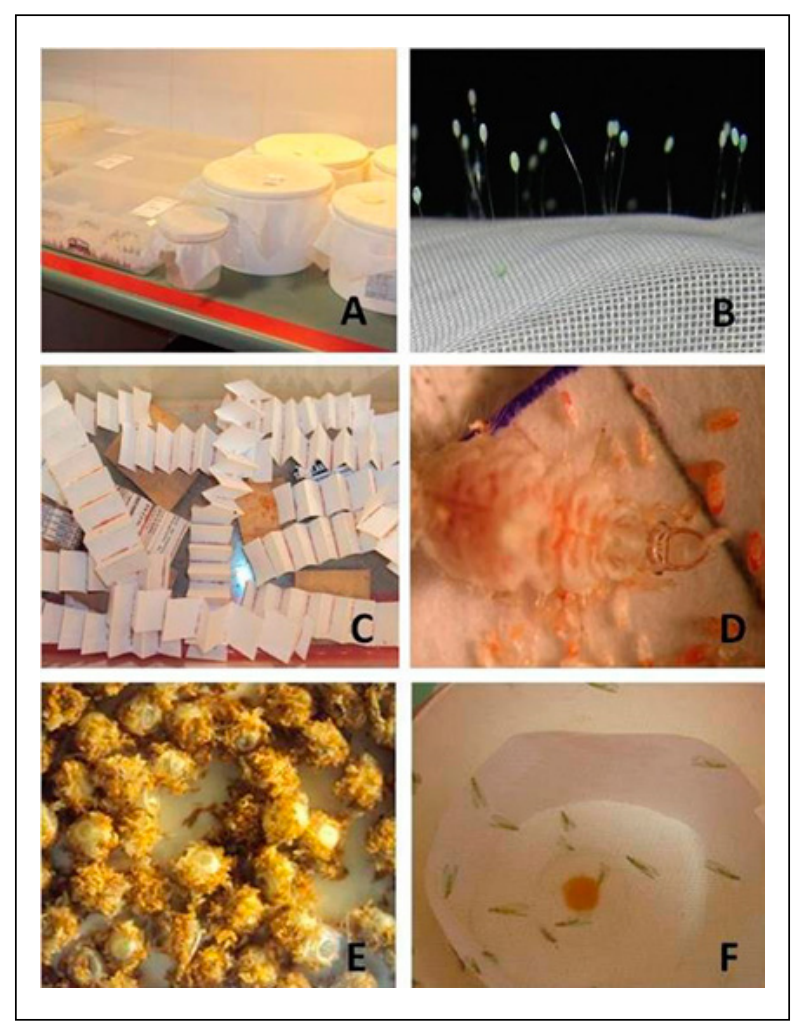

Figure 2. a. Rearing of $C$. (C.) lineafrons; b. Eggs; c. Larval feeding box; d. Larvas; e. Pupal stage; F. Adults.

\section{Data analysis}

Data obtained in the laboratory such as number of prey offered and consumed, date of emergence of $C$. $(C$.) lineafrons larvae, oviposition, number of individuals adults placed in each container and numbers of eggs laid daily were registered into spreadsheets.

The mean, average and percentage of eggs predated by $C .(C$.) lineafrons were calculated. In addition, the survival of the different life stages (egg, larva and pupa) of lacewing was determined, as well as, the adult longevity and number of eggs laid per female per day fed with $B$. tabaci eggs and $S$. cerealella eggs. The analysis was carried out using the Statistica 6.0 (StatSoft, 2001) software.

\section{RESULTS}

Of the total of 90 eggs of Chrysopodes (C.) lineafrons chosen at the beginning of the assay, only 71 hatched, and of these 34 were fed with B. tabaci eggs and 37 
with Sitotroga cerealella eggs. During the ingest assay it was observed that a total of 34 individuals reached the adult state, 28 fed with S. cerealella eggs and 6 with Bemisia tabaci eggs.

\section{Ingestion assay}

In general, the larvae of $C$. $(C$.) lineafrons consumed an average of 127.04 ( \pm 40.2) eggs of B. tabaci and 44 ( \pm 19.04) eggs of $S$. cerealella per day. When each larval stage was evaluated separately, it was observed that the larva I of $C$. (C.) lineafrons consumed a maximum of 556 eggs of B. tabaci and 189 eggs of $S$. cerealella, the larva II consumed 531 eggs of B. tabaci and 240 eggs $S$. cerealella, while larva III consumed 619 eggs of B. tabaci and 150 eggs of $S$. cerealella per day (Table 1). On the other hand, the developmental time of the different larval stages were similar between larvae I and II, whereas for larvae III was shorter. With regard to developmental time of $C$. (C.) lineafrons an average of 45 days was recorded when the larvae were fed with of $B$. tabaci eggs and 35 days with $S$. cerealella eggs (Table 2).

Table 1. Daily eggs consumption of $C$. (C.) lineafrons larvae fed with B. tabaci eggs and S. cerealella eggs.

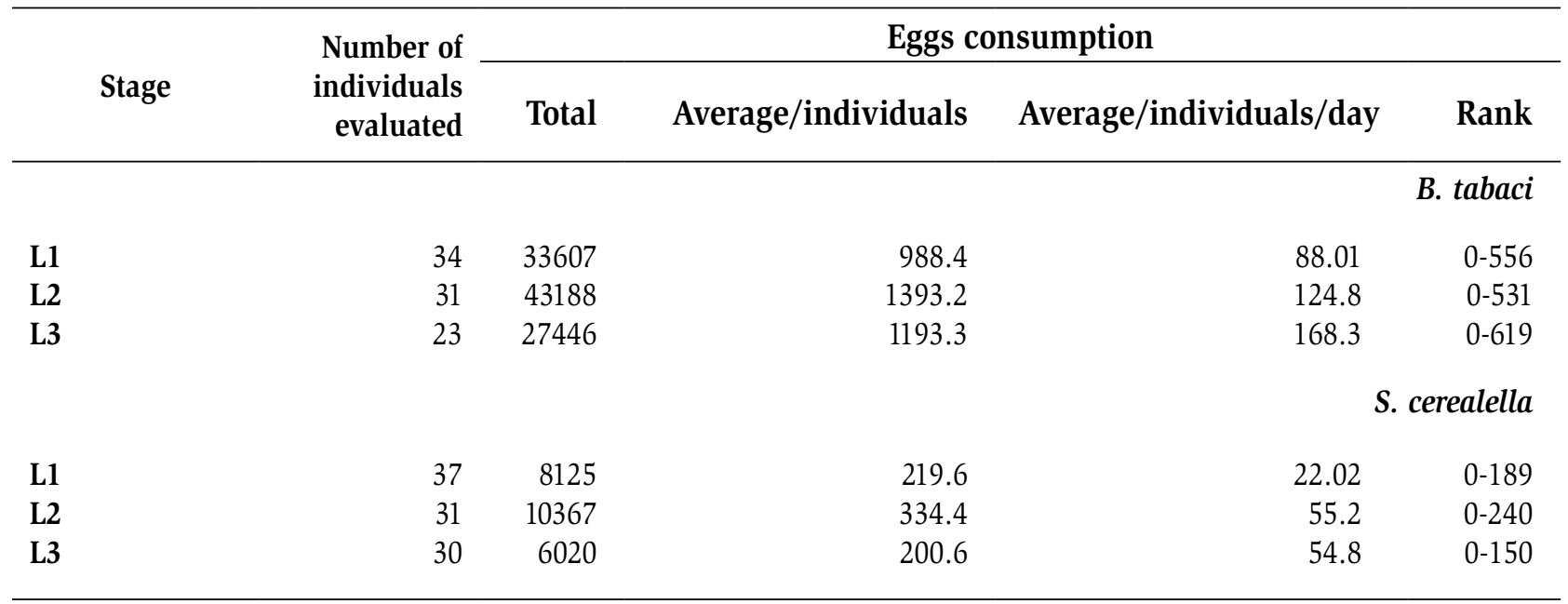

Table 2. Developmental time of different stages of $C$. (C.) lineafrons fed with B. tabaci eggs and S. cerealella eggs.

\begin{tabular}{lcc}
\hline Stage & Mean \pm SD & Life cycle duration \\
\hline B. tabaci & & \\
L1 & $11.23 \pm 3.28$ & $45.2 \pm 3.54$ \\
L2 & $11.16 \pm 6.02$ & \\
L3 & $7.09 \pm 4.37$ & \\
Pupa & $15.75 \pm 2.99$ & \\
S. cerealella & & $34.9 \pm 5.04$ \\
L1 & $9.97 \pm 4.21$ & \\
L2 & $6.06 \pm 4.27$ & \\
L3 & $3.66 \pm 2.47$ & \\
Pupa & $15.21 \pm 3.51$ & \\
\hline
\end{tabular}

Means \pm SD followed by $\mathrm{P}<0.05$ 


\section{Survival, longevity and oviposition}

In general, survival of eggs of $C$. (C.) lineafrons was $81.1 \%$. The immature stages of $C$. (C.) lineafrons fed with $B$. tabaci eggs showed lower survival (8.2\%) than those fed with $S$. cerealella eggs (30.1\%). Lacewings survival decreased significantly from the larval stage toward the adult stage, for both individuals fed with B. tabaci eggs as $S$. cerealella eggs (Figure 3).
Regarding to $C$. (C.) lineafrons adults longevity, a greater number of specimens was observed from larvae fed with $S$. cerealella eggs, as well as greater longevity of 41 days approximately, while the larvae fed with $B$. tabaci eggs it was 20 days (Figure 4a). Oviposition of $C$. (C.) lineafrons was also higher in females fed with $S$. cerealella eggs (Figure 4b).

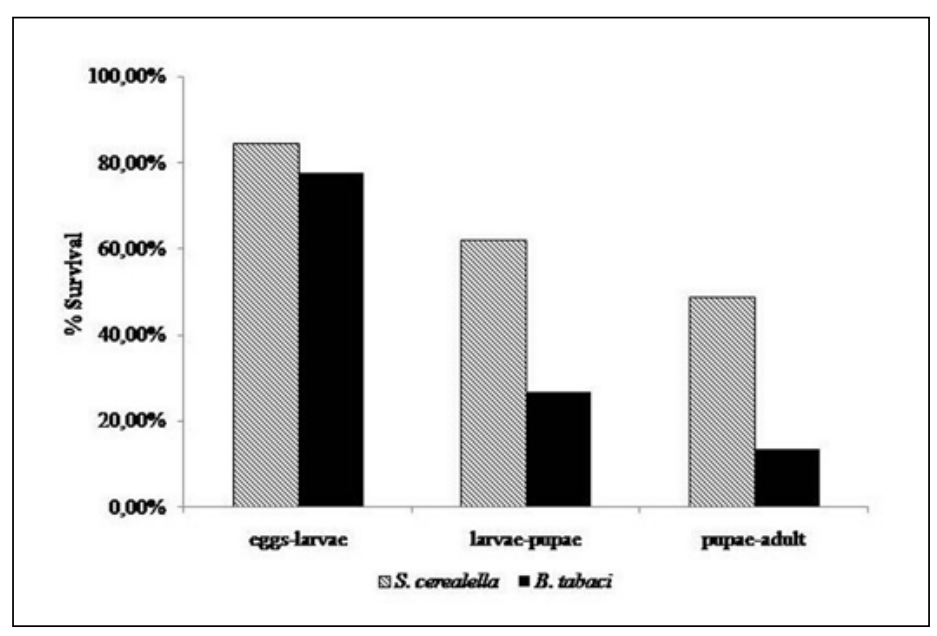

Figure 3. Viability of different developmental stages of $C$. (C.) lineafrons fed with B. tabaci eggs and S. cerealella eggs.

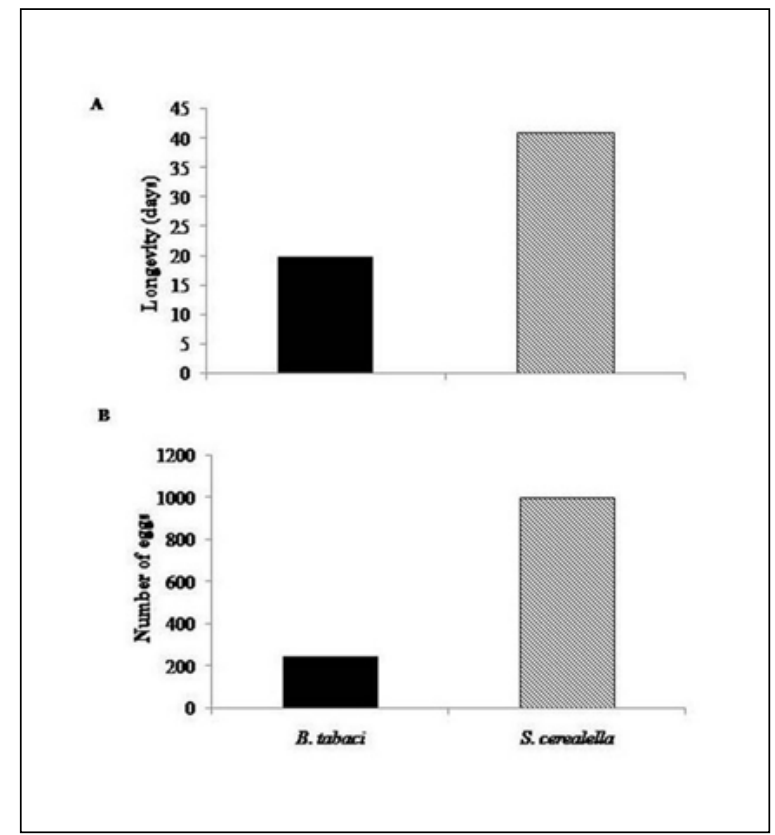

Figure 4. (a) Longevity and (b) Oviposition of $C$. (C.) lineafrons adult fed with B. tabaci and S. cerealella eggs. 


\section{DISCUSSION}

This study represents the first record of $C$. $(C$.) lineafrons predation capacity over $B$. tabaci eggs in Argentina, pointing at this specie as a potential biological control agent. It should be noted that this lacewing specie was recently cited in the province of Tucumán, northwestern Argentina (Ortega et al., 2014).

Regarding to the ingest capacity, the $C$. $(C$.) lineafrons larvae consumed a greater amount of $B$. tabaci eggs per day than $S$. cerealella eggs, standing out the larva II, respectively. These results are comparable with those reported by Legaspi et al. (1994), who determined that a greater number of $B$. tabaci eggs were necessary for the development of larvae III of Chrysoperla rufilabris Bumeister. Other studies cite that Chrysoperla carnea Stephens was able to eat up 200.5 nymphs of B. tabaci and 171.8 nymphs of Amrasca devastans Distant (Nisar-Syed et al., 2005) and that the larvae can consume about 8000 eggs of $S$. cerealella and 510 pupae of $B$. tabaci throughout its development (Gallardo et al., 2005). As well, Legaspi et al. (1994) determined that $C$. rufilabris larvae consume an average of 531.55 eggs of $B$. tabaci per day, whereas Avila et al. (2009) reported that Chrysoperla argentina Steimann larvae ingested an average of 275 eggs of $B$. tabaci per day. This behavior can be attributed to that reported by Nisar-Syed et al. (2005), who determined that the prey density has a strong influence on the predation potential, i.e. the consumption of number of egg increase as the prey density was increased.

Furthermore, it was observed that $C$. (C.) lineafrons presented a developmental time of 45 days when they were fed with $B$. tabaci eggs and 35 days with $S$. cerealella eggs. Regarding this, investigations performed by Ramirez-Delgado et al. (2007) with Ceraeochrysa sp. nr. cincta determined that total developmental time, from egg until adult emergence was 29 days when they were fed with $S$. cerealella eggs. Moreover, Legaspi et al. (1994) recorded an increased duration of larval developmental time in $C$. rufilabris fed with $B$. tabaci eggs compared with those fed with $S$. cerealella eggs; however, Nisar-Syed et al. (2005) recorded that $C$. carnea present a shorter developmental time when they were fed with $B$. tabaci eggs compared that with A. devastans eggs.

Survival of $C$. (C.) lineafrons as the life cycle progresses decreased for both individuals those fed with $B$. tabaci eggs and those fed with $S$. cerealella eggs. These results agree with those obtained by Ramirez-Delgado et al. (2007), who determined a steadily decreased over time of $C$. sp. nr. cincta survival fed with $S$. cerealella eggs. Longevity of $C$. (C.) lineafrons adults fed with S. cerealella eggs was 41 days and 20 days with $B$. tabaci eggs, results that agree with those reported by Ramírez-Delgado et al. (2007), who determined a greater longevity for adults of $C$. sp. nr. cincta fed with S. cerealella eggs.

Generally, survival, longevity and number of eggs laid per female of $C$. $(C$.) lineafrons was greater when they were fed with $S$. cerealella eggs than with $B$. tabaci eggs. In this regard, Giffoni et al. (2007) determined that $C$. externa only completed its life cycle when being fed with S. cerealella; while Legaspi et al. (1994) recorded that $C$. rufilabris larvae showed a greater preference for $S$. cerealella eggs than for $B$. tabaci eggs.

It has been observed that $C$. $(C$.) lineafrons present a similar behavior to other lacewing species but with the peculiarity that the predation efficiency is much higher, which would represent an excellent tool to an efficient biological control of B. tabaci in tomato crops. Therefore, we can conclude that the larval stages of $C$. (C.) lineafrons require a greater number of $B$. tabaci eggs than of $S$. cerealella eggs to complete its life cycle; larvae II and III of $C$. (C.) lineafrons consume more B. tabaci eggs; larval I stage is longer than the other two larval stages; survival and longevity of $C$. $(C$.) lineafrons adults was greater in individuals fed with $S$. cerealella eggs, as well as the number of eggs laid per female was higher.

In general, we can say that $C$. $(C$.) lineafrons feed with $S$. cerealella reached a complete development in a shorter time, whereas individuals feeding with B. tabaci required a higher density of the prey to complete the development since the number of eggs offered failed to meet nutritional needs. These results would indicate that the greater efficiency of the predator would be given when the availability and number of whitefly are greater than those offered in the present study. Therefore, survival, longevity and oviposition are determined by the nutritional value of the prey, that is, $C$. (C.) lineafrons require a higher number of whitefly eggs to increase these values and indicate their potential as a control agent. 


\section{ACKNOWLEDGEMENTS}

We thank to the Estación Experimental Agroindustrial Obispo Colombres (EEAOC), Las Talitas, Tucumán for the collaboration and funding for this research. This research was supported by the Consejo Nacional de Investigaciones Científicas Técnicas (Project Number 20110100687).

\section{REFERENCES}

Adams, P.A. and Penny, N. 1987. Neuroptera of Amazon Basin, Part 11a. Introduction and Chrysopini. Acta Amazonica 15: 413-479.

Ávila, A.L., Arias, M.J., Ortega, S. and Toledo, S. 2009. Ingesta de huevo de mosca blanca por Chrysoperla argentina, Resúmenes de las III Jornadas de Jóvenes Investigadores 2009. Tucumán, Argentina.

Berlinger, M.J. 1986. Host plant resistance of Bemisia tabaci. Ecosystems Environment 17: 69-82.

Brown, J. 1993. Evaluación crítica sobre los biotipos de mosca blanca en América, de 1989 a 1992. In: Mata, M. De., Dardon Avila, D.E., Salguero, N., V.E., Editors. Memorias del taller Centroamericano y del Caribe sobre Moscas Blancas. CATIE, Turrialba.

Brown, J., Coats, S.A., Bedford, I.D., Markhan, P.G., Bird, J. and Frohlich, D.R. 1995. Caracterization and distribution of esterase electromorphs in the Whitefly, Bemisia tabaci (Genn.) (Homóptera: Aleyrodidae). Biochemical Genetics 33: 205-213.

Byrne, N.D., Bellows, T.S.Jr. and Parrella, M.P. 1990. Whiteflies in agricultural systems, In: Gerling, D., Editor. Whiteflies: their bionomics, pest status and management, Intercept Ltd., Andover.

Díaz-Aranda, L.M. and Monserrat, V.J. 1990. Estadios larvarios de los Neurópteros Ibéricos. VI: Chrysoperla carnea (Stephens, 1836), Chrysoperla mediterránea (HÖlzel, 1972) y Chrysoperla ankylopteryformis Monserrat y Díaz-Aranda, 1989. (Insecta, Neuroptera: Chrysopidae. Boletín de Sanidad Vegetal Plagas 16: 675-689.

Flores, G., Reguilón, C., Alderete, G. and Kirschbaum, D.S. 2015. Liberación de Chrysoperla argentina (Neuroptera: Chrysopidae) para el control de Trialeurodes vaporariorum (Hemíptera: Aleyrodidae) en invernáculo de pimiento en Tucumán, Argentina. Intropica 10: 28-36.
Gallardo, J., Vargas-Camplis, J.J., López-Arroyo, J.I. and Reyes-Rosas, M.A. 2005. Uso y manejo de Crhysoperla carnea. Patronato para la investigación fomento y sanidad vegetal. Centro regional de estudios y reproducción de organismos benéficos. H. matamoros, Tamaulipas. http:// home.satx.rr.com/avargas/CHRYSOPERLA.htm. Accesed December 19, 2005.

Giffoni, J., Valera, N., Diaz, F. and Vasquez, C. 2007. Ciclo Biológico de Chrysoperla externa (Hagen) (Neuroptera: Chrysopidae) alimentada con diferentes presas. Bioagro 19: 109-113.

González-Olazo, E.V., Toledo, S. and Zaia, G. 1999. Nuevas citas de Chrysopidae (Neuroptera: Planipennia) para la Argentina. Acta Zoológica Lilloana 45: 151-152.

González-Olazo, E.V. and Reguilón, C. 2008. Orden Neuroptera. In: Claps, L.E., Debandi, G., Roig-Juñent, S., Editors. Biodiversidad de Insectos de la Argentina II. Sociedad Entomológica Argentina. Argentina.

Hagler, J.R., Jackson, C.J., Isaacs, R. and Machtley, S.A. 2004. Foranging behavior and prey interactions by a guild of predators on various lifestages of Bemisia tabaci. Journal of Insect Science 4:1-13.

Holguin, C.M., Mendoza, C.E., Tauber, C.A. and Belotti, C. 2004. Especies de la Familia Chrysopidae asociadas al cultivo de Yuca Manihot esculenta Crantz. Centro Internacional de Agricultura Tropical (CIAT). Cali. Colombia. Póster. http://ciat-library.ciat.cgiar.org/articulos_ciat/ipm/pdfs/ socolen_04_holguin.pdf. Accesed March 5, 2016.

Legaspi, J.C., Carruthers, R.Y. and Nordlund, D.A. 1994. Life history of Chrysoperla rufilabris (Neuroptera: Chrysopidae) provided sweet potato whitefly Bemisia tabaci (Homoptera: Aleyrodidae) and other food. Biological Control 4: 178-184.

López-Ávila, A. 2005. Biología y control biológico de las moscas blancas. Centro de investigación Tibaitatá, Bogotá, pp. 1-13. https://tallertesis.files.wordpress. com/2015/03/bycbdemoscasblancas3.pdf. Accesed September 29, 2017.

López, S.N., Viscarret, M.M. and Botto, E.N. 1999. Selección de la planta hospedera y ciclo de desarrollo de Trialeurodes vaporariorum (Westwood) (Homoptera: Aleyrididae) sobre zapallito (Cucurbita máxima Duch.; Cucurbitales: Cucurbitacea) y tomate (Lycopersicum esculentum Mill.; Tubiflorales: Solanacea). Boletín de Sanidad Vegetal Plagas 25: 21-29. 
Monserrat, V. and Freitas, S. 2005. Contribución al conocimiento de los crisópidos de Coquimbo, Patagonia y Tierra del Fuego (Argentina y Chile) (Insecta, Neuroptera, Chrysopidae). Graellsia 61: 163-169.

Nisar-Syed, A., Ashfak, M. and Khan, S. 2005. Comparision of development and predation of Chrysoperla carnea (Neuroptera: Chrysopidae) on different densities of two hosts (Bemisia tabaci and Amrasca devastans). Pakistan Entomologist 27: 41-44.

Núñez, Z.E. 1988. Ciclo biológico y crianza de Chrysoperla externa y Ceraeochrysa cincta (Neuroptera: Chrysopidae). Revista Peruana de Entomología 31: 76-82.

Ortega, E.S., Veggiani-Aybar, C.A., Avila, A.L., Heredia, F. and Reguilón, C. 2014. First report of Chrysopodes (Chrysopodes) lineafrons (Neuroptera: Chrysopidae) in Tucumán province, Northwestern Argentina. Florida Entomologist 97: 266-268.

Polack, L.A. 2005. Manejo integrado de moscas blancas. Boletín Hortícola 31:1-7.
Ramírez-Delgado, M., López-Arroyo, J.L., GonzálesHernández, A. and Badii-Zabeh, M.H. 2007. Rasgos Biológicos y Poblacionales del depredador Ceraeochrysa sp. nr. cincta (México) (Neuroptera: Chrysopidae). Acta Zoológica Mexicana 23: 79-95.

Reguilón, C., Alderete, G. and Flores, G.C. 2011. Chrysoperla argentina (Neuroptera: Chrysopidae) un enemigo natural promisorio para el control de la mosca blanca (Trialeurodes vaporariorum) en cultivo de pimiento en invernaderos Lules, Tucumán. Horticultura Argentina 30(73): 55.

STATSOFT INC. 2001. STATISTICA (data analysis software system), versión 6 .

Viscarret, M. 2000. Estudios biológicos sobre Aleyrodidae de importancia económica (Insecta: Hemiptera) con énfasis en el complejo Bemisia tabaci (Gennadius) y su posible control biológico. Tesis doctoral, Facultad de Ciencias Exactas y Naturales, Universidad Nacional de Buenos Aires, Argentina.

Fecha de recepción: 09/03/2017

Fecha de aceptación: 14/07/2017

Publicado en línea: 14/09/2017

Para citar este artículo: Ortega E. S., Veggiani-Aybar, C., Ávila, A.L. and Reguilón C. 2017. New Records of predation on eggs of Bemisia tabaci (Hemiptera: Aleyrodidae) by Chrysopodes (Chrysopodes) lineafrons (Neuroptera: Chrysopidae) in northwestern Argentina. Intropica 12(2): 101-108. DOI: http://dx.doi.org/ 10.21676/23897864.2284. 